\title{
Robin Arthur
}

\section{INTRODUCTION}

As a research student at Cambridge in the 1970s, one was constantly aware of key papers that established techniques which formed the background for the research that each student was performing and which the students took rather for granted. Two of those techniques, the use of miniature strain-gauged load cells to measure boundary stresses in element tests or model boundary value problems and $\mathrm{X}$-radiography to discover information concerning displacements and density changes within soil elements and models, had emerged from the research of Robin Arthur at Cambridge a little more than a decade earlier (Arthur et al., 1964) (Fig. 1).

\section{BOUNDARY STRESS MEASUREMENT}

When he appointed Ken Roscoe to a lectureship in the Cambridge University Engineering Department after the war, John Baker challenged Roscoe to design foundations for his plastically designed steel frames which would have defined stiffness, fixity and capacity. A major element of such foundations is the development of lateral pressure against the sides of the foundation. This spurred experimental work at different scales, culminating in the 'big rig', in which a model wall could be translated or rotated in any combination of movements towards or away from the tank of sand. In Robin's time, the wall had an active face $150 \mathrm{~mm}$ wide and $150 \mathrm{~mm}$ high, but subsequently this was increased to $330 \mathrm{~mm}$ high and $190 \mathrm{~mm}$ wide in a tank of sand that was $1.52 \mathrm{~m}$ high and $2.44 \mathrm{~m}$ long - a seriously 'big' rig (James \& Bransby, 1970). Robin, recognising the need to measure the distribution of stresses generated on the wall by the retained sand, developed pioneering load cells which transmitted the boundary stresses to thin strain-gauged webs, strategically arranged to be sensitive particularly to boundary normal stress, boundary shear stress and the gradient of normal stress (the moment applied by the normal stresses). These cells were located in the mid-plane of the wall to escape from boundary friction effects. The load cells of 1961 were somewhat chunky (Arthur et al., 1964), but over the next 10-15 years or so successive research students refined the design of the cells; the workshop technicians expertly machined cells of ever smaller size and ever more subtly complex geometry; the nimble fingers of Vera Johnson attached the strain gauges and the connecting wires.

\section{RADIOGRAPHIC STUDY OF INTERNAL \\ DEFORMATION}

In order to discover what was happening within the sand in the vicinity of the moving wall, Robin devised a radiographic technique using X-rays both to detect variations in density in the sand (evidence of significant dilation accompanying shearing) and to record the locations of lead markers placed in the mid-plane of the sand. There was much debate concerning dilation bands. The two types of radiographic evidence were combined to support the assertion that the dilation bands - interpreted as shear localisations - were zero-extension lines so that, once a constant-volume critical state had been attained, the zero extension directions would be orthogonal; before that they would be oriented at $\pi / 4-\psi / 2$

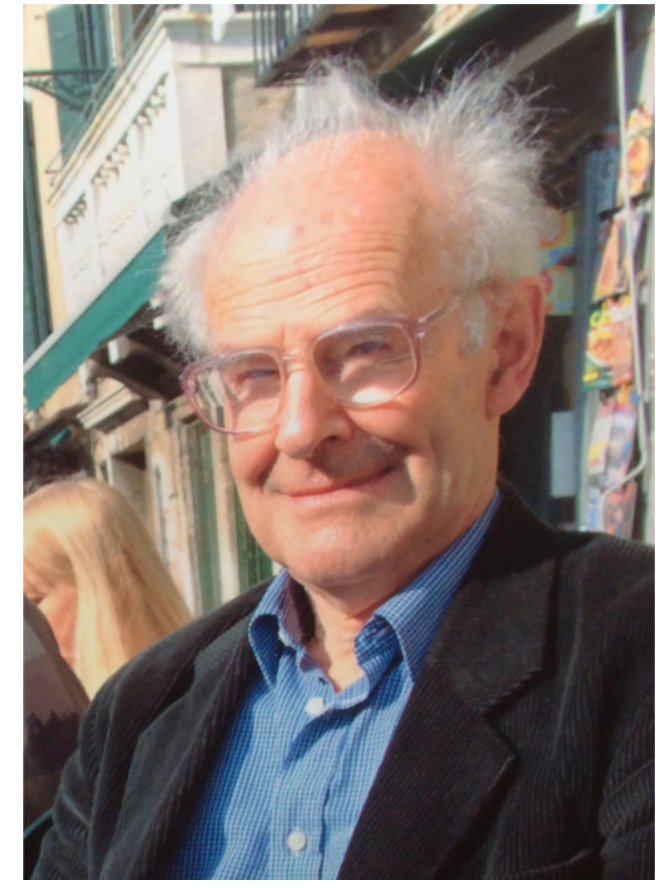

Fig. 1. Robin Arthur (1932-2016) in 2004 (photograph provided by Mervyn Arthur)

each side of the major principal strain increment where $\psi$ is the angle of dilation.

Today digital image correlation is used to provide full-field displacement information from photographs of deforming models (Viggiani \& Hall, 2008). In the 1960s, the extraction of displacements or density changes from radiographs was a major chore made somewhat simpler by the development of the 'spotchaser' by the late 'Jimmy' James (1932-2016). Once the spotchaser (located in a darkened room in the basement of the Baker building) had been taught the approximate coordinates of the lead shot, it could then, without further human intervention, follow a regular search routine to accurately identify the edges of the radiographic image and thence the centre of each marker, in the original and subsequent radiographs - assuming that the displacement between successive radiographs was not excessive.

\section{LABORATORY ELEMENT TESTING}

The simple shear apparatus with which Roscoe was obsessed throughout his brief soil mechanics research career (Roscoe, 1953, 1970) fitted neatly into the radiographic studies of shear localisation in the 'big rig' because the horizontal plane in the simple shear apparatus is forced to be a direction of zero extension. Robin had developed a cubical cell true triaxial apparatus with Bruce Menzies (Arthur \& Menzies, 1972) at about the same time that Hon-Yim Ko (Ko \& Scott, 1967) working with Ron Scott at CalTech had also produced a true triaxial apparatus, which used a symmetrical arrangement of flexible pressure bags to impose three principal stresses on a cubical sample. There was some debate as to the role played by an internal frame that kept the pressure bags apart along the edges of the 


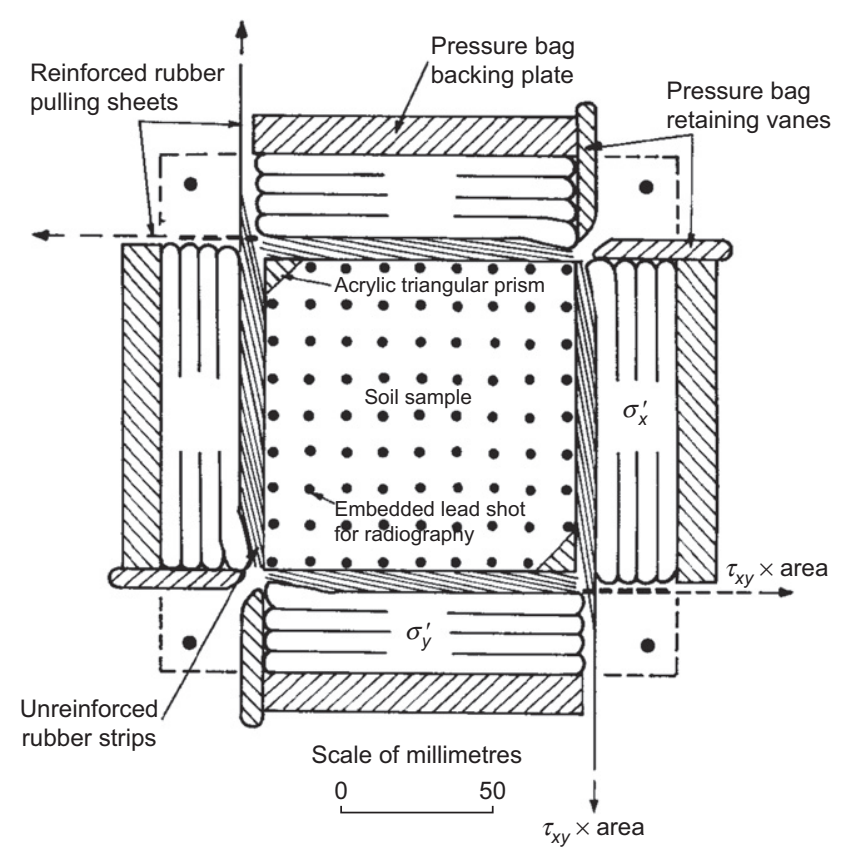

Fig. 2. Directional shear cell: application of normal and shear stresses to flexible boundaries (Arthur et al., 1977a, 1977b)

cube - the two cells having adopted slightly different designs. Loading with flexible membranes inevitably limited the deformations that could be imposed on any face of the cube, but for stiffer soils - Robin was testing sands - this was not a major disadvantage and the resulting apparatus was simpler and more compact than the Hambly design of true triaxial apparatus with its nested sliding rigid platens (Hambly, 1969). Hambly had designed a rigid platen biaxial - plane strain - apparatus using the same principles as the subsequent true triaxial apparatus, and Robin, much concerned with the friction between the sample and the restraining plane face, devised a membrane system which reduced friction and was linked to the moving platens. These low-friction devices were made by Robin for chemical engineering/powder technology groups in Bergen and Germany.

Simplicity of design and operation was cast to the winds, however, in his design of the directional shear cell with his close collaborator at University College, London (UCL), Treve Dunstan (Arthur et al., 1977b). This used a subtle arrangement of very extensible rubber strips to apply shear stresses to the four lateral faces of a plane strain specimen, with the normal stresses applied by flexible bags as in the cubical cell (Fig. 2). This, like the $1 \gamma 2 \varepsilon$ apparatus subsequently developed at Grenoble, provided, in principle, full control over the plane strain stress state, escaping from the fixed orientation of the zero extension direction implicit in the simple shear apparatus. The flexible faces of the containing membrane had to be extensible in order that all components of strain could develop freely. (The $1 \gamma 2 \varepsilon$ apparatus, on the other hand, is a plane stress device (testing two-dimensional rod materials) in which subtle interleaving of platen sections permits the rigid platens to change in length as required, while still maintaining full support of the sample.) Samples were prepared by pluviation and lead markers were placed in the mid-plane for subsequent radiographic observation.

The directional shear cell at UCL was essentially copied for Jack Germaine at the Massachusetts Institute of Technology (MIT), MA, USA and for John Peters at the US Army Corps of Engineers Waterways Experiment Station at Vicksburg, USA. At about the same time, Hon-Yim Ko and Stein Sture built a broadly similar apparatus at the University of Colorado, Boulder, CO, USA. Robin's directional shear cell is the only plane strain laboratory test device that comes close to providing a strain field which can be measured and which can be more or less homogeneous over the entire specimen, and which permits controlled rotation of principal axes.

It is fair to say that the use of these directional shear cells has not been especially extensive because of the complexity of conducting each test. The simultaneous control of shear stresses and changes in length of the faces to which the shear stresses were applied provided severe challenges (Alawaji et al., 1990). There were also concerns about the complete uniformity of the strain field over the entire cross-section of the specimen, including the corner regions. However, Robin himself conducted series of careful tests in which he was able to observe, using X-rays, the internal localisations and to relate the orientations of these dilational features to the orientation of the major principal stress.

Traditional geotechnical design using Mohr-Coulomb models assumes that a limiting stress state will occur on planes of maximum stress obliquity and that rupture planes should therefore coincide with these, having orientations $\theta_{\mathrm{C}}=\pi / 4-\phi / 2$ with the major principal stress: this is the Coulomb orientation. The extensive radiographic studies at Cambridge on the model retaining wall showed clear evidence of localisations - in the form of localised dilation features - having orientation $\theta_{\mathrm{R}}=\pi / 4-\psi / 2$ with the major principal strain increment: this is the Roscoe orientation. Angles of dilation are always considerably lower than angles of friction, so these pairs of conjugate features are usually readily distinguished. However, Robin found clear evidence of features which more or less bisected the Coulomb and Roscoe orientations $\theta_{\mathrm{A}}=\pi / 4-[\phi / 4+\psi / 4]$ (Arthur et al., 1977a, 1977b). Robin's justification for this 'Arthur' orientation was elaborate and empirical (Fig. 3). However, both Vermeer (1982) and Vardoulakis \& Sulem (1995) produced theoretical arguments in support of the Arthur orientation as one of three orientations of bifurcation features which might develop depending on the constraints provided by application to and observation of a particular boundary value problem.

The understanding of the significance of principal stress rotations in soils is still incomplete and is not satisfactorily treated in many constitutive models. Robin had little confidence in contemporary developments in constitutive modelling but would probably have reluctantly approved of the use of discrete-element modelling to provide possibilities for acknowledging the observed particle-scale mechanisms which can then be scaled up for continuum models.

Many of Robin's observations have been confirmed in physical and numerical experiments. Heterogeneity in sand samples develops almost as soon as shearing of a sample has begun (Hall et al., 2010). Structural changes in the interactions of sand particles as loading increases result in evolution of anisotropy of stiffness properties. The use of imaging techniques such as high-resolution tomography in laboratory testing has also improved dramatically in the last few decades, aided by extraordinary developments in device resolution and by the accompanying rise in computing power, which is essential for managing the vast quantities of data that imaging produces. Much of the conceptual framework needed to exploit these capabilities was already present in Robin's pioneering work from the late 1950s.

\section{LIFE AND CAREER}

Jonathan Robin Francis Arthur was born in 1932 and went to Sedbergh school, at that time in Yorkshire (now in 


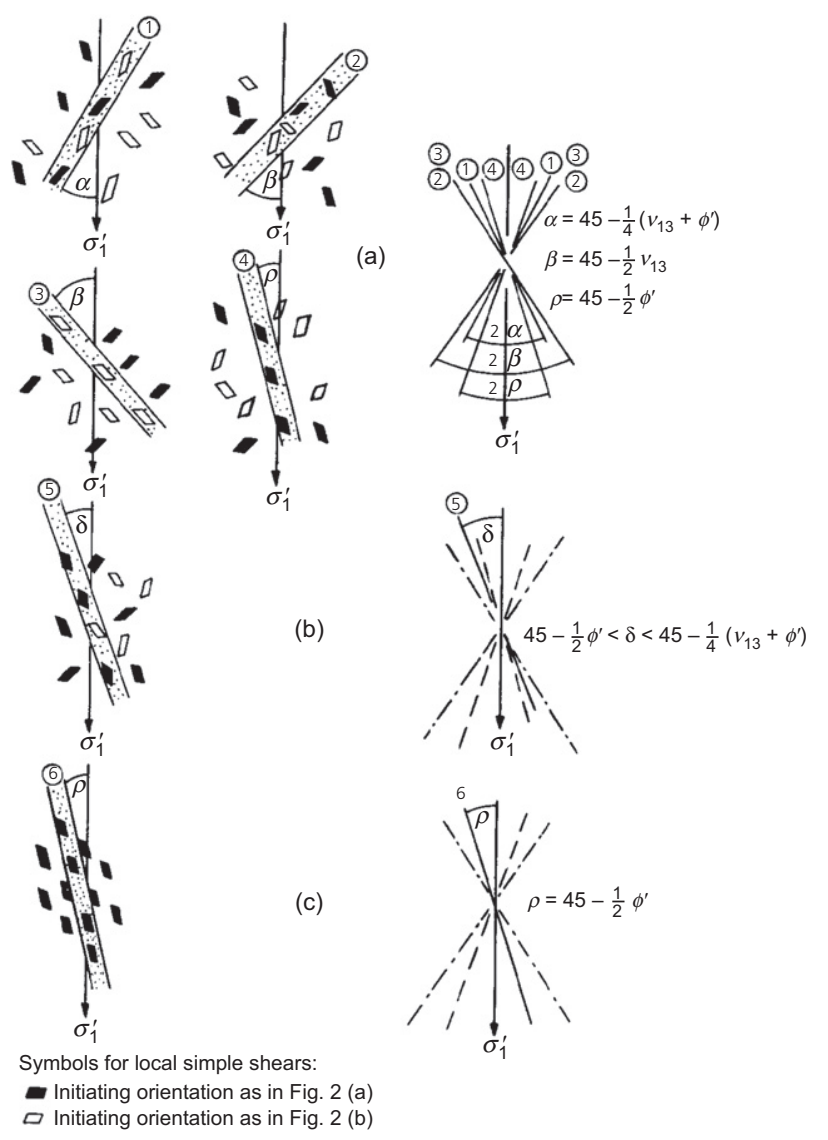

Fig. 3. Distributions of local simple shears triggering rupture layers at the orientations indicated: (a) symmetric; (b) partially asymmetric; (c) fully asymmetric (Arthur et al., 1977a, 1977b)

Cumbria). On leaving school he completed National Service and went up to Emmanuel College, Cambridge in 1952 to read mechanical sciences, graduating in 1955. After a short period working in London he returned to Cambridge in 1957 with an ICI scholarship to carry out soil mechanics research under the direction of Ken Roscoe. He was awarded a PhD degree in 1962.

He had a lifelong interest in boats, sailing and the sea. Dinghy sailing, and latterly small yacht sailing, was a pleasure that continued for much of his life. He became an enthusiastic oarsman for Emmanuel. During his research studies at Cambridge he met Margaret through the Barwin School of Dancing in Emmanuel Road and they were married in 1959.

In 1962 he took up a lectureship at UCL, at the invitation of Henry Chilver. He had an active and productive research career at UCL until his retirement in 1989. He was invited to lecture in Europe, North America and Japan on his test apparatus and the insights that they gave into the behaviour of sands. During 1979-1980 he spent a year at MIT, building and installing their directional shear cell as well as designing soil experiments for the National Aeronautics and Space Administration (NASA) and the US space programme. Although tempted to leave the UK, he chose to stay at UCL, becoming Professor of Geotechnical Engineering in 1985 .

On retirement in 1989, he and Margaret moved to Suffolk where, having transformed a World War I army hut into a comfortable home, he could enjoy his love of the constantly changing sea and the coast and the migrant and resident birds. There must be many children and grandchildren of geotechnical engineers who recall, as Robin's son does, the distinct advantages of having a father 'who knew a thing or two about sand and engineering'. Family holidays in Cornwall included team activities in damming of apparently modest water courses, which led to the subsequent disruption of picnics and deck chairs over a surprisingly large area of beach. Richmal Crompton's William would have been proud.

For many years after his retirement, Robin was a diligent leader of the local residents' association and campaigner for better drainage and sea defences after particularly high spring tides in Southwold. He spent considerable energy impressing on the local council the need to take seriously the threat to the coastline, and to property along the road towards the harbour.

Robin also had a deep interest in art. His knowledge of paintings was phenomenal. One student recalls standing next to him in a gallery in Soho and staring at some drawings on display during a lunchtime break. 'That's a Goya!' he would say. He was right. An ability to recognise the styles of different artists even in hurried pencil sketches is a rare skill: he had an art encyclopaedia in his head. Margaret was an excellent artist: one of her paintings of a test on a concrete shell structure hangs in the Baker building common room in Cambridge.

He was a very kind man. His research students basked in his gracious approach to life. They were privileged to have known and worked with him.

$\mathrm{He}$ is survived by his wife Margaret, son Mervyn and grandson Caspar.

David Muir Wood, Division of Civil Engineering, Dundee University, Dundee, UK

Curt Koenders, Department of Engineering and the Environment, University of Southampton, Southampton, UK

\section{ACKNOWLEDGEMENTS}

The authors are grateful to Mervyn Arthur, Andrew Schofield, Jacques Desrues, Stein Sture and Bruce Menzies for their assistance in gathering information for this obituary.

\section{REFERENCES}

Alawaji, H., Alawi, M., Ko, H. Y., Sture, S., Peters, J. F. \& Muir Wood, D. (1990). Experimental observations of anisotropy in some stress-controlled tests on dry sand. In Yielding, damage, and failure of anisotropic solids (EGF5) (ed. J. P. Boehler), pp. 251-264. London, UK: Mechanical Engineering Publications.

Arthur, J. R. F. \& Menzies, B. K. (1972). Inherent anisotropy in a sand. Géotechnique 22, No. 1, 115-128, http://dx.doi.org/ 10.1680/geot.1972.22.1.115.

Arthur, J. R. F., James, R. G. \& Roscoe, K. H. (1964). The determination of stress fields during plane strain of a sand mass. Géotechnique 14, No. 4, 283-308, http://dx.doi.org/ 10.1680/geot.1964.14.4.283.

Arthur, J. R. F., Chua, K. S. \& Dunstan, T. (1977a). Induced anisotropy in a sand. Géotechnique 27, No. 1, 13-30, http://dx.doi.org/10.1680/geot.1977.27.1.13.

Arthur, J. R. F., Dunstan, T., Al-Ani, Q. A. J. L. \& Asssadi, A. (1977b). Plastic deformation and failure in granular media. Géotechnique 27, No. 1, 53-74, http://dx.doi.org/10.1680/geot. 1977.27.1.53

Hall, S., Muir Wood, D., Ibraim, E. \& Viggiani, C. (2010). Localised deformation patterning in $2 \mathrm{D}$ granular materials revealed by digital image correlation. Granular Matter 12, No. 1, 1-14.

Hambly, E. C. (1969). A new true triaxial apparatus. Géotechnique 19, No. 2, 307-309, http://dx.doi.org/10.1680/geot.1969.19. 2.307 .

James, R. G. \& Bransby, P. L. (1970). Experimental and theoretical investigations of a passive earth pressure problem. Géotechnique 20, No. 1, 17-37, http://dx.doi.org/10.1680/geot.1970.20.1.17.

Ko, H. Y. \& Scott, R. F. (1967). A new soil testing apparatus. Géotechnique 17, No. 1, 40-57, http://dx.doi.org/10.1680/geot. 1967.17.1.40. 
Roscoe, K. H. (1953). An apparatus for the application of simple shear to soil samples. In Proceedings of the 3rd international conference on soil mechanics and foundation engineering, Switzerland, 1953 (ed. Organising Committee, ICOSMFE), vol. 1, pp. 186-191. Zurich, Switzerland: Imprimerie Berichthaus.

Roscoe, K. H. (1970). The influence of strains in soil mechanics (10th Rankine Lecture). Géotechnique 20, No. 2, 129-170, http://dx.doi.org/10.1680/geot.1970.20.2.129.

Vardoulakis, I. \& Sulem, J. (1995). Bifurcation analysis in geomechanics. Glasgow, UK: Blackie Academic and Professional, Chapman and Hall.

Vermeer, P. A. (1982). A simple shear-band analysis using compliances. In Proceedings of the IUTAM symposium on deformation and failure of granular materials (eds P. A. Vermeer and H. J. Luger), pp. 493-499. Rotterdam, the Netherlands: A. A. Balkema.

Viggiani, G. \& Hall, S. A. (2008). Full-field measurements, a new tool for laboratory experimental geomechanics. In Proceedings of the 4th symposium on deformation characteristics of geomaterials (eds S. Burns, P. Mayne and J. Santamarina), vol. 1, pp. 3-26. Amsterdam, the Netherlands: IOS Press.

\section{BIBLIOGRAPHY}

Arthur, J. R. F. (1962). Strains and lateral force in sand. PhD thesis, University of Cambridge, Cambridge, UK.

Arthur, J. R. F. (1972a). Discussion: the meaning and measurement of basic soil parameters. In Stress strain behaviour of soils: proceedings of the Roscoe memorial symposium (ed. R. H. G. Parry), pp. 382-385. Henley-on-Thames, UK: G. T. Foulis.

Arthur, J. R. F. (1972b). New techniques to measure new parameters. In Stress strain behaviour of soils: proceedings of the Roscoe memorial symposium (ed. R. H. G. Parry), pp. 340-346. Henley-on-Thames, UK: G. T. Foulis.

Arthur, J. R. F. (1977). Industrial radiography in soil mechanics research. Brit. J. Non-destructive Testing 19, No. 1, 9-13.

Arthur, J. R. F. \& Assadi, A. (1977). Ruptured sand sheared in plane strain. In Proceedings of the 9th international conference on soil mechanics and foundation engineering, Tokyo, Japan, vol. 1, pp. 19-22.

Arthur, J. R. F. \& Dalili, A. (1979). On the lubrication of rubber surfaces. Géotechnique 29, No. 1, 96-98, http://dx.doi.org/ 10.1680/geot.1979.29.1.96.

Arthur, J. R. F. \& Dunstan, T. (1969). Radiography measurements of particle packing. Nature 223, No. 5203, 464-468.

Arthur, J. R. F. \& Dunstan, T. (1970). Radiological techniques developed to describe particle packing. J. Powder Technol. 3, No. 1, 195-207.

Arthur, J. R. F. \& Dunstan, T. (1982). Rupture layers in granular media. In Deformation and failure of granular materials: International Union of Theoretical and Applied Mechanics symposium on deformation and failure of granular materials, Delft, 31 August-3 September (eds P. A. Vermeer and H. J. Luger), pp. 453-459. Rotterdam, the Netherlands: Balkema.

Arthur, J. R. F. \& Dunstan, T. (1988). Discussion: sixth Géotechnique symposium in print: the engineering application of direct and simple shear testing. Géotechnique 38, No. 4, 651-652, http://dx.doi.org/10.1680/geot.1988.38.4.651.

Arthur, J. R. F. \& Menzies, B. K. (1968). Correspondence: a new soil testing apparatus. Géotechnique 18, No. 2, 271-274, http://dx.doi.org/10.1680/geot.1968.2.271.

Arthur, J. R. F. \& Menzies, B. K. (1972a). Inherent anisotropy in a sand. Géotechnique 22, No. 1, 115-128, http://dx.doi.org/ 10.1680/geot.1972.22.1.115.

Arthur, J. R. F. \& Menzies, B. K. (1972b). Discussion: inherent anisotropy in a sand. Géotechnique 22, No. 3, 541, http://dx.doi. org/10.1680/geot.1972.22.3.541.

Arthur, J. R. F. \& Menzies, B. K. (1973). Discussion: inherent anisotropy in a sand. Géotechnique 23, No. 1, 128-130, http://dx. doi.org/10.1680/geot.1973.23.1.128.
Arthur, J. R. F. \& Phillips, A. B. (1972). Discussion: inherent anisotropy in a sand. Géotechnique 22, No. 3, 537-538, http://dx.doi. org/10.1680/geot.1972.22.3.537.

Arthur, J. R. F. \& Phillips, A. B. (1975). Homogeneous and layered sand in triaxial compression. Géotechnique 25, No. 4, 799-815, http://dx.doi.org/10.1680/geot.1975.25.4.799.

Arthur, J. R. F. \& Roscoe, K. H. (1961). An earth pressure cell for the measurement of normal and shear stresses. Civ. Engng Public Works Rev. 56, No. 659, 765-770.

Arthur, J. R. F. \& Roscoe, K. H. (1965). An examination of edge effects in plane strain model earth pressure tests. In Proceedings of the 6th international conference on soil mechanics and foundation engineering, Montreal, Canada, vol. 2, pp. 363-368.

Arthur, J. R. F. \& Shamash, S. J. (1967). A note on the accuracy of displacement measurements in soils using an X-ray method. Civil Engng Public Works Rev. 62, No. 729, 455-456.

Arthur, J. R. F. \& Shamash, S. J. (1970). Sampling of cohesionless soils without disturbing the particle packing. Géotechnique $\mathbf{2 0}$, No. 4, 439-440, http://dx.doi.org/10.1680/geot.1970.20.4.439.

Arthur, J. R. F., James, R. G. \& Roscoe, K. H. (1964). The determination of stress fields during plane strain of a sand mass. Géotechnique 14, No. 4, 283-308, http://dx.doi.org/10.1680/ geot.1964.14.4.283.

Arthur, J. R. F., Chua, K. S. \& Dunstan, T. (1977a). Induced anisotropy in a sand. Géotechnique 27, No. 1, 13-30, http://dx.doi.org/10.1680/geot.1977.27.1.13.

Arthur, J. R. F., Dunstan, T., Al-Ani, Q. A. J. L. \& Asssadi, A. (1977b). Plastic deformation and failure in granular media. Géotechnique 27, No. 1, 53-74, http://dx.doi.org/10.1680/geot. 1977.27.1.53.

Arthur, J. R. F., Dunstan, T., Al-Ani, Q. A. J. L. \& Asssadi, A. (1978). Discussion: plastic deformation and failure in granular media. Géotechnique 28, No. 1, 125-128, http://dx.doi.org/ 10.1680/geot.1978.28.1.125.

Arthur, J. R. F., Chua, K. S. \& Dunstan, T. (1979). Dense sand weakened by continuous principal stress direction rotation. Géotechnique 29, No. 1, 91-96, http://dx.doi.org/10.1680/geot. 1979.29.1.91.

Arthur, J. R. F., Chua, K. S., Dunstan, T. \& Rodriguez del Camino J. I. (1980). Principal stress rotation: a missing parameter. J. Geotech. Engng Div., ASCE 106, No. 4, 419-433.

Arthur, J. R. F., Bekenstein, S., Germaine, J. T. \& Ladd, C. C. (1981). Stress path tests with controlled rotation of principal stress directions. In Laboratory shear strength of soils (eds R. N. Yong and F. C. Townsend), Special Technical Publication 740, pp. 516-540. Philadelphia, PA, USA: American Society of Testing and Materials.

Arthur, J. R. F., Dunstan, T. \& Enstad, G. G. (1985). Determination of the flow function by means of a cubic plane strain tester. Int. J. Bulk Solids Storage in Silos 1, No. 2, 7-10.

Arthur, J. R. F., Dalili, A. \& Dunstan, T. (1989). Discussion: Sixth Géotechnique symposium in print: the engineering application of direct and simple shear testing. Géotechnique 39, No. 1, 140-144, http://dx.doi.org/10.1680/geot.1989.39.1.139.

Ogunbekun, O. O., Dalili, A., Arthur, J. R. F. \& Dunstan, T. (1988). Distributed disturbance and constraints in soils. In Micromechanics of granular materials (eds M. Satake and J. T. Jenkins), pp. 235-244, Studies in applied mechanics No. 20. Amsterdam, the Netherlands: Elsevier.

Roscoe, K. H., Arthur, J. R. F. \& James, R. G. (1963). The determination of strains in soils by an X-ray method. Civil Engng Public Works Rev. 58, No. 684, 873-876 and No. 685, 1009-1012.

Wong, R. K. S. \& Arthur, J. R. F. (1985a). Determination and uses of strain distributions in sand samples. Geotech. Testing J., ASTM 8, No. 3, 101-110.

Wong, R. K. S. \& Arthur, J. R. F. (1985b). Induced and inherent anisotropy in sand. Géotechnique 35, No. 4, 471-481, http://dx.doi.org/10.1680/geot.1985.35.4.471.

Wong, R. K. S. \& Arthur, J. R. F. (1986). Sand sheared by stresses with cyclic variations in direction. Géotechnique 36, No. 2, 215-226, http:/dx.doi.org/10.1680/geot.1986.36.2.215. 